\title{
Realization of «Victory» and «Defeat» frames in sports Internet-discourse: problem of focusing
}

\author{
A.G. Pisareva \\ Samara National Research University, Samara, Russian Federation \\ E-mail: anastasia1202@yandex.ru. ORCID: http://orcid.org/0000-0002-1830-5174
}

\begin{abstract}
The relevance of the problem of realization of the frames «Victory» and «Defeat» that are linguistically represented in the sports Internet-discourse is due to the fact that in the recent decades scholars both in Russia and abroad develop the theoretical grounds of discourse analysis and pay special attention to different kinds of institutional and professional discourses, and sports discourse possesses two important features - aims and participants; thus, sports discourse belongs to the group of institutional discourses and is of great interest for researchers. The aim of the research became the identification of methods that are applied in order to change the focus of the frame; in the course of the study the author solves the following tasks: description of the constituents of the cognitive event model, carrying out linguistic research of sports Internet-discourse fragments and defining the pragmatic goals of the author that in turn influence the frame as a whole. The match reports which are found in the news sections of sport teams' websites were used as the research materials. The study is devoted to the headings of the reports and introductions to them. It is these parts of the articles that contain information about the match outcome that is the basis for the frames under analysis. In the article the following methods were applied: critical discourse analysis as well as quantitative and qualitative methods in the framework of content analysis. Lexical units that were singled out were analyzed from both morphological and semantic perspectives. The study of modern sports Internet-discourse has demonstrated that the authors of match reports tend not only to convey the information about the match results to the readers of the web-site but also to influence their opinion by forming a particular interpretation. The conducted analysis makes it possible to conclude that an intentional shift of focus frame is achieved with the help of various lexical units, word combinations and, especially, evaluative adjectives. Key words: sports discourse; Internet-discourse; event; frame; frame focus.

Citation. Pisareva A.G. Realization of «Victory» and «Defeat» frames in sports Internet discourse: problem of focusing. Vestnik Samarskogo universiteta. Istoriia, pedagogika, filologiia = Vestnik of Samara University. History, pedagogics, philology, 2021, vol. 27, no. 1, pp. 129-135. DOI: http://doi.org/10.18287/2542-0445-2021-27-1-129-135. (In English) Information on the conflict of interests: author declares no conflict of interest.
\end{abstract}

(C) Pisareva A.G., 2021

Anastasiya G. Pisareva - $2^{\text {nd }}$ year postgraduate student, 10.02.04 - Germanic languages, assistant lecturer of the Department of English Philology, Samara National Research University, 34, Moskovskoye shosse, Samara, 443086, Russian Federation.

\section{НАУЧНАЯ СТАТЬЯ}

УДК 811.111

Дата поступления: 26.12.2020 рецензирования: 27.01.2021 принятия: 26.02.2021

\section{Реализация фреймов «Победа» и «Поражение» в спортивном интернет-дискурсе: проблема фокусировки}

\author{
А.Г. Писарева \\ Самарский национальный исследовательский университет \\ имени академика С.П. Королева, г. Самара, Российская Федерация \\ E-mail: anastasia1202@yandex.ru. ORCID: http://orcid.org/0000-0002-1830-5174
}

\begin{abstract}
Аннотация: Актуальность проблемы реализации фреймов «Победа» и «Поражение», которые получают свою языковую репрезентацию в спортивном интернет-дискурсе, обусловлена тем, что в последние десятилетия зарубежные и отечественные лингвисты разрабатывают теоретические основы анализа дискурса, уделяя особое внимание отдельным видам институционального и профессионального дискурсов, а спортивный дискурс, коммуникация в рамках которого обладает двумя системообразующими признаками (цели и участники общения), является одним из институциональных дискурсов и представляет большой интерес для исследования. Целью стало выявление методов, посредством которых осуществляется изменение фокусировки фрейма события; автор в ходе исследования решает следующие задачи: описание конституентов когнитивной модели события в спортивном дискурсе и проведение лингвистического анализа фрагментов спортивного интернет-дискурса с целью определения прагматических целеустановок его автора, которые оказывают влияние на фрейм в целом. Материалом исследования послужили послематчевые репортажи, представленные в новостных разделах вебсайтов спортивных команд; в центре внимания находились заголовки репортажей и вступления к ним. Это обусловлено тем, что именно эти составные части статей содержат информацию об исходе того или иного матча,
\end{abstract}


Вестник Самарского университета. История, педагогика, филология. 2021. Т. 27, № 1. С. 129-135 130 Vestnik of Samara University. History, pedagogics, philology, 2021, vol. 27, no. 1, pp. 129-135

который лежит в основе исследуемых фреймов. В статье применялись следующие методы: критический дискурсанализ, метод количественного и качественного анализа в рамках контент-анализа. Выделенные языковые единицы рассматривались с точки зрения морфологии и семантики. Изучение современного спортивного интернет-дискурса показало, что авторы послематчевых репортажей стремятся не только донести до читателей веб-страницы информацию о его результате, но и повлиять на их мнение, сформировав определенную интерпретацию. Проведенный анализ позволяет сделать вывод, что происходит целенаправленная фокусировка фрейма при помощи различных лексем, словосочетаний и, в частности, оценочных прилагательных.

Ключевые слова: спортивный дискурс; интернет-дискурс; событие; фрейм; фокусировка фрейма.

Цитирование. Писарева А.Г. Реализация фреймов «Победа» и «Поражение» в спортивном интернет-дискурсе: проблема фокусировки // Вестник Самарского университета. История, педагогика, филология. 2021. Т. 27 , № 1. C. 129-135. DOI: http://doi.org/10/12287/2542-0445-2021-27-1-129-135.

Информация о конфликте интересов: автор заявляет об отсутствии конфликта интересов.

\section{(C) Писарева А.Г., 2021}

Анастасия Григорьевна Писарева - аспирант, специальность 10.02.04 - Германские языки, ассистент кафедры английской филологии, Самарский национальный исследовательский университет имени академика С.П. Королева, 443086, Российская Федерация, г. Самара, Московское шоссе, 34.

\section{Introduction}

Sport has always been an important aspect of social life. Nowadays it forms a global industry that includes not only clubs, teams, leagues, athletes, merchandise and sporting associations, but also government departments of sport and recreation, the media, various educational organizations, researches, consultants and volunteers etc. [Smith, Stewart 2015, p. 16].

The present paper deals with sports Internetdiscourse and the realization of particular frames within the cognitive situation model of an Event. The discursive fragments in the form of match reports subjected to analysis were collected from the News section of the official web-sites of the rugby teams. All of the matches took place during the autumn 2020.

\section{Literature review}

Cognitive processes of sport communication in the information society of today are under analysis of many scholars. For instance, N. Kislitsyna and E. Novikova claim that sport communication involves a specific influence directed at both mental and physical spheres of life [Kislitsyna, Novikova 2017, p. 32]. E. Filimonova states that, in the coordinates of the institutional discourse space, sport discourse denotes communication in the sphere of and about sport and sporting activity with regard to specific features of the communicants, priority concepts and values, chronotope, communicative aims, strategies and tactics (Filimonova 2019, p. 8).

It is also essential to take into account the fact that sport today has become widely mediated and new cultural development comprised of sport and media is considerably influenced by new technologies. "Mediatization in sport" which has become especially prominent in the last decade, is being researched in modern linguistic studies [Caldwell 2020, p. 2]. According to A. Hepp, the subject of mediatization is "the interrelation between the change of media and communication, on the one hand, and the change of (fields of) culture and society, on the other hand" [Hepp, Hjarvard, Lundby 2015, p. 319].

This article focuses on the frames realized within sports Internet-discourse. A lot of scholars based their research on the notion of "semantic frame". A. Kibrik states that in order to understand communicative intention, it is necessary to possess a model of knowledge or a basic frame (Kibrik 2003, p. 37). Thus, the notion of "frame" is compulsory for any text analysis, especially during its analysis in the discourse structures. Such frames provide a background of beliefs and experiences so as to interpret the lexical meaning of the word. M.-Ch. Liu and Ch.-E. Chang mention the following definition: frame is a set of shared knowledge or background information within which the meaning is defined [Liu, Chang 2005 , p. 432]. According to N. Boldyrev, frame is a multicomponent concept in the form of information "package", the knowledge of a stereotypical situation. He points out the complexity of frame that is due to the fact that it includes a situation [Boldyrev 1999, p. 64]. Furthermore, the idea that frames could be extracted from discourses has long been accepted and developed through different analytical routes [Vicari 2010, p. 522]. W.A. Gamson and Ch. Ryan claim that facts take on their meaning by being embedded in frames, themes which organize thoughts, rendering some facts as relevant and significant and others as irrelevant and trivial [Gamson, Ryan 2005]. Thus, the focus of a particular frame can be modified in order to form a specific interpretation. Frame focusing is defined as deliberate omitting or, on the contrary, emphasizing of various information [Ivanova 2016, p. 127]. The aim here is to form a public opinion of an event by offering an interpretation of a particular frame.

\section{Methodology}

This article deals with cognitive models and frames within sports discourse. In modern studies the latter has a wider meaning than "linguistics of sport" or "language of/in sport". It refers to the "ways" of using language and that allows us to deal with the range of language varieties, genres, registers, lexes, grammars and phonology/graphology that constitute the discourse of sports [Caldwell, Walsh, Vine, Jureidini 2017, p. 19]. This research applied a critical mixed method discourse analysis in order to analyze the ways of shifting the frame focus within sports Internet-discourse. The mixed method refers to both 
quantitative and qualitative methods in the framework of content analysis and critical discourse analysis. According to $\mathrm{K}$. Krippendorf, content analysis involves "a systematic reading of texts, images, and symbolic matter, not necessary from an author's or user's perspective" [Krippendorf 2013, p. 10]. As for the critical discourse analysis, we employed it in order to read "above the level of a sentence, of ways to create meaning, coherence, and accomplish purpose" [Gee, Handford 2012, p. 1].

\section{Findings}

The cognitive models of a socially significant event in the sphere of sport, which can be a match/game/ fixture, are represented in the match report. While the body of this specific news item describes the course of the match, the introduction as well as headings (and subheadings if present) focus on the result of an event. A frame of "Victory" or "Defeat" is formed using various linguistic means. That corresponds with the idea that sports discourse genres have their own linguistic and stylistic peculiarities the aim of which is to activate the emotional perception of the reader. Different levels of stylistics and vocabulary are often mixed which makes the text a memorable one and attracts the reader's attention [Novikova 2019, p. 7-8].

Our task is to single out the constituents of a cognitive model that are capable of changing the focus of the particular frame and analyze the methods applied to achieve this. In order to fulfill this task we are going to take into consideration the pragmatic goals of the author of the report as news items under analysis are devoted to the same matches written by winning and losing sides. The primary frame focus is shifted through its peripheral elements or subframes. In the framework of event analysis in the sports Internet-discourse they tend to match the constituents of a cognitive situation model. The constituents under analysis correspond to the traditional model of a news item: Event - WHO, WHAT, WHERE, WHEN, WHY, HOW and possess the information about PARTICIPANTS, the EVENT itself, LOCATION, TIME, OBJECTIVES and CIRCUMSTANCES respectively.

First of all, we turned to the fragments of match reports representing the perspectives of both winning and losing sides, i.e. "Victory" and "Defeat" frames. The examples are given in the tables 1 and 2 .

Table 1

Таблищуа 1

The representation of the "Victory" frame

Представление фрейма «Победа»

\begin{tabular}{|c|c|}
\hline 1.1 & $\begin{array}{l}\text { Saints crowned Champions in greatest ever Grand Final finish } \\
\text { Saints are back to back Super League Champions after an incredible 8-4 Grand Final win over arch rivals } \\
\text { Wigan Warriors at the KCOM Stadium, after a breath taking last second try by Jack Welsby secured the win for } \\
\text { Kristian Woolf's side (Saint Helens 2020). }\end{array}$ \\
\hline 2.1 & $\begin{array}{l}\text { Wigan reach } 2020 \text { Grand Final } \\
\text { Wigan Warriors reach the } 2020 \text { Betfred Super League Grand Final after a hard fought victory over Hull FC at } \\
\text { the DW Stadium. } \\
\text { A brilliant second half from the Cherry and Whites brought about } 16 \text { unanswered points to see them past Andy } \\
\text { Last's side and put them within } 80 \text { minutes of the Super League trophy (Wigan Warriors 2020). }\end{array}$ \\
\hline 3.1 & $\begin{array}{l}\text { Wigan win League Leaders`shield } \\
\text { Wigan Warriors sealed first place and the League Leaders'Shield with a hard fought win over Huddersfield } \\
\text { Giants on Friday night. } \\
\text { Tries from Sam Powell, Jackson Hastings and Zak Hardaker guided Adrian Lam's side to their first top of the } \\
\text { table finish since } 2012 \text { (Wigan Warriors 2020). }\end{array}$ \\
\hline 4.1 & $\begin{array}{l}\text { Warriors seal nail-biting win in Round } 1 \\
\text { Warriors showed tremendous character to start the 2020/21 Gallagher Premiership season with a gutsy but } \\
\text { nerve-jangling victory over tenacious Irish at Sixways (Worcester Warriors 2020). }\end{array}$ \\
\hline 5.1 & $\begin{array}{l}\text { SAINTS DISPATCH CATALANS TO REACH SECOND CONSECUTIVE GRAND FINAL! } \\
\text { Saints booked our place in a second consecutive Grand Final after an impressive eight try victory over Cata- } \\
\text { lans Dragons at the Totally Wicked Stadium. } \\
\text { Kevin Naiqama stole the headlines with a hat-trick and the victory means we will face Wigan Warriors in the } \\
\text { Grand Final next Friday at Hull's KCOM Stadium (Saint Helens 2020). }\end{array}$ \\
\hline 6.1 & $\begin{array}{l}\text { WIRE HOLD ON TO REACH SEMI FINALS } \\
\text { Warrington advanced to the last four of the Challenge Cup after narrowly beating St Helens in a thrilling tie at } \\
\text { the AJ Bell Stadium (Warrington Wolves 2020). }\end{array}$ \\
\hline 7.1 & $\begin{array}{l}\text { SAINTS GO TOP WITH DOMINANT WIN OVER GIANTS } \\
\text { Saints scored nine tries in a dominant win over Huddersfield Giants which saw Kristian Woolf's men go top of } \\
\text { the Super League table for the first time under his reign (Saint Helens 2020). }\end{array}$ \\
\hline 8.1 & $\begin{array}{l}\text { GIANTS SECURE NAIL-BITING WIN } \\
\text { Huddersfield Giants slim play-off hopes rema } \\
\text { Giants will be thankful for hat-trick hero Jerm }\end{array}$ \\
\hline
\end{tabular}


Вестник Самарского университета. История, педагогика, филология. 2021. Т. 27, № 1. С. 129-135

132 Vestnik of Samara University. History, pedagogics, philology, 2021, vol. 27, no. 1, pp. 129-135

Таблица 2

Представление фрейма «Поражение»

The representation of the "Defeat" frame

\begin{tabular}{|c|c|}
\hline 1.2 & $\begin{array}{l}\text { Wigan narrowly lose in Grand Final } \\
\text { Wigan Warriors fell short of Grand Final glory as St Helens grabbed a late try at the KCOM Stadium. } \\
\text { A second half try from winger Jake Bibby put Wigan ahead, but a dramatic final minute saw Saints snatch vic- } \\
\text { tory (Wigan Warriors 2020). }\end{array}$ \\
\hline 2.2 & $\begin{array}{l}\text { Hull FC's hopes of reaching a first Grand Final since } 2006 \text { were dashed by Wigan Warriors, who ran out 29-2 } \\
\text { victors in a bone-crunching semi-final at the DW Stadium (Hull FC 2020). }\end{array}$ \\
\hline 3.2 & $\begin{array}{l}\text { YOUNG GIANTS BEATEN BY LEAGUE LEADERS } \\
\text { Huddersfield Giants finished the regular season with a narrow loss in a pulsating yet defensive game at Emerald } \\
\text { Headingley against Wigan Warriors, who lifted the League Leaders Shield after the game (Huddersfield Giants } \\
\text { 2020). }\end{array}$ \\
\hline 4.2 & $\begin{array}{l}\text { London Irish fell to a narrow 11-10 loss to Worcester Warriors on the opening day of the 2020/21 season. } \\
\text { In what was a closely-fought encounter from start to finish, the Exiles were just edged out of a nip-and-tuck } \\
\text { contest (London Irish 2020). }\end{array}$ \\
\hline 5.2 & $\begin{array}{l}\text { V THE SEMI-FINAL } \\
\text { been beaten by St Helens } 48-2 \text { in the Super Leag }\end{array}$ \\
\hline 6.2 & $\begin{array}{l}\text { SAINTS DEFEATED IN QUARTER FINAL AFTER TIGHT CUP AFFAIR } \\
\text { Saints lost out in the Coral Challenge Cup quarter final after a tight, end-to-end cup tie ended with Warrington } \\
\text { Wolves coming out 20-18 victors at the AJ Bell Stadium as Kristian Woolf's men tasted defeat for the first time } \\
\text { since the restart (Saint Helens 2020). }\end{array}$ \\
\hline 7.2 & $\begin{array}{l}\text { UFFER SAINTS DEFEAT } \\
\text { om St Helens dispatched an injury hit Giants to secure a } 54-6 \text { victory at Headingley } \\
\text { ants 2020). }\end{array}$ \\
\hline 8.2 & $\begin{array}{l}\text { TIGERS COME UP SHORT AGAINST GIANTS } \\
\text { A brave effort from Castleford came up short as Huddersfield reeled them in to win 31-19 in the Betfred Super } \\
\text { League. } \\
\text { The Tigers headed to the Halliwell Jones Stadium without a raft of key players and a new-look spine as they } \\
\text { searched for a vital win to keep their play-off hopes alive but they couldn't hold on despite leading midway }\end{array}$ \\
\hline
\end{tabular}

Six subframes or cognitive model constituents mentioned above can be found in the introductions to match reports. The variety of their representation is vivid on the linguistic level. Firstly, the element PARTICIPANTS can be separated into several subgroups: the names of the teams (Wigan Warriors, London Irish, Catalans Dragons, St Helens), their nicknames (the Cherry and Whites, Saints), coach's name in a possessive case + noun (Adrian Lam's side, Kristian Woolf's men), names of individual players (Jack Welsby, winger Jake Bibby, Kevin Naiqama). We believe that such variety is determined by the reporter's pragmatic goal: whether it is emphasizing the aspect of unity within a team or a club or stressing the role and the merits of an individual (coach or player) for the common success.

Secondly, the EVENT itself has double representation: on the one hand, the position of the match in the championship structure is emphasized (Grand Final, semi-final, quarter final, Round 1); on the other hand, various synonyms to the word "match" including contextual ones can be observed (game, encounter, contest, (cup) tie, cup affair). We believe that by pointing out the level of the game (the tournament stage) the author of the piece stresses the significance of this particular affair both for the team and for rugby world in general. At the same time, the use of synonyms is aimed at, first of all, avoiding lexical repetition, and, in addition, at highlighting the aspect of interaction between two groups (tie, encounter) which is entertaining for spectators and vital for achieving the result.

The third element, LOCATION, is narrowed down to the name of the stadium (at the Totally Wicked Stadium, the AJ Bell Stadium, at Emerald Headingley); it is represented less extensively than the other constituents. As for TIME, this subframe possesses a scarce representation (on Friday night) and, as well as LOCATION, does not contribute to the process of frame focusing.

As regards the constituent WHY, which emphasizes the objectives of the participants and their actions, it is also not presented as widely as the other ones. That is due to the fact that regardless of the aims the teams set themselves the match has already taken place and nothing can alter its outcome. Nevertheless, we may get some idea about what the aspirations of the teams were (to search for a vital win to keep their play-off hopes alive, Hull FC's hopes of reaching a first Grand Final since 2006).

During our discourse analysis of the event based on the match report as a whole, the constituent HOW 
used to denote the RESULT of a particular match (or player's move) and such representations are present in the discourse fragments under analysis. They may also be categorized and fall into several subgroups: lexical units meaning progress and regress in general (to advance, to come up short, to lose, to fall to a loss), word combinations indicating both the result and its consequences for team's career (to be crowned champions, to reach final, to finish the season with a loss) and, finally, expressions that are common for journalistic sports discourse (to run out victors, to secure a win, to seal a win, to beat, to suffer defeat, to taste defeat). These expressions represent a kind of "trite metaphor" - a metaphor whose original interpretation has been lost, they do carry specific meaning, however, they no longer convey the image. For instance, the verb "to beat" originates from hitting someone or something with your hands and is more commonly used for physical fight rather than the outcome of a game. The expression "to run out victors" comes from the Latin times and the word "victor" itself used to denote "winner of a battle, test of strength, etc.; conqueror; famous warrior". Nowadays only the first meaning is still commonly used ("the winner of a competition or battle, one that defeats an enemy or an opponent"). Due to the frequency of mentioning and the variety of the applied linguistic means this component clearly stands out among the rest, thus, justifying Victory and Defeat being the centre of respective frames.

In the present research, however, HOW also corresponds to the MANNER of the teams' performance, the examples of which will be cited further on.

The ways of ascribing additional meaning to these constituents were in the focus of the next stage of the undertaken research. While such elements as LOCATION and TIME do not receive any connotation, the others cease being completely neutral. We consider that this fact can be explained by the reporter's desire to shift the frame focus and convey additional meaning. Mainly, this is achieved with the help of various evaluative adjectives, for instance, the opponents can be called tenacious (with the meaning of "being very determined and not willing to give up") in order to emphasize the hardships the team went through to beat them; nonetheless, different methods are also applied.

As for the first component, PARTICIPANTS, we may also note the use of past participle combination "an injury hit Giants" which is mentioned twice: in the heading and in the introduction of the match report describing Huddersfield Giants' defeat. The pragmatic goal of the author clearly stands out - it is vital to account for having been beaten and not to lose the support of faithful fans. Thus, by drawing attention to the fact that the sportsmen were not in the best condition and, probably, by making the fans feel sorry for the team, the initial negative reaction can be alleviated. Nouns are also used for the matter of influencing public opinion. Positive image of a player is created by calling him "a hat-trick hero", thus, emphasizing his role in the victory. In order to highlight the meaning of the victory itself one of the teams dubbed their opponents "arch rivals", a collocation contributing to the fans understanding how important the battle and its outcome were for the team.

Evaluative adjectives that accompany the denominations of the EVENT are of two different kinds: in the reports of the winning teams, they are not numerous and carry general positive meaning incredible, thrilling. The reports of the losing teams clearly emphasize the tense atmosphere of the battle: bone-crunching, pulsating yet defensive. Some adjectives demonstrate that the chances of two teams had been equal (closely-fought, end-to-end, tight about a game where players or teams play well and it is difficult to know who will win, nip-and-tuck - a competition where opponents have an equal chance of winning). We believe these adjectives play a considerable role in shifting the focus of the frame: the team lost the game but sportsmen had fought fiercely and shouldn't be considered completely defeated.

Likewise, various adjectives are used with Victory or Win which correspond to the RESULT of the match. In the reports of the winning teams, within the frame "Victory", we have come across the following examples: a hard-fought victory, nail-biting win, a gutsy but nerve-jangling victory, an impressive victory, a dominant win. While conveying the intense atmosphere of the clash, these epithets also show that the win was well-deserved, consequently, directing the focus not only at the win itself, but also at the team's efforts. Different approach is employed in the reports of the opposite side. First of all, word combinations with adjective "narrow" and its derivative (to narrowly lose, to finish the regular season with a narrow loss, to fall to a narrow 11-10 loss) and the expression to be edged out ("to be beaten in something such as a competition or election by a small amount") are used in order to emphasize the fact that the losing team was quite close to running out victors as though the win had been stolen from them. Furthermore, the focus of the frame shifts towards depicting the opponents as aggressors which is done with such expressions as to snatch victory ("to quickly take the opportunity to do something or to quickly steal something from somebody"), to dispatch ("to get rid of someone or something in a fast and effective way") while the other team "suffered defeat". Such implicit assessment contributes to forming an interpretation and, consequently, shaping an opinion of the readers.

The same reason can account for the use of the following expressions: to grab a late try, a ruthless performance (of the opponents) that characterize the MANNER of the teams playing. These combinations belong to the fragments of the Internet-discourse from the web-sites of the clubs that were beaten in the matches described; thus, they belong to the "Defeat" frame. At the same time, the frame "Victory" contains descriptive adjectives that convey the meaning of 
Вестник Самарского университета. История, педагогика, филология. 2021. Т. 27, № 1. С. 129-135 134 Vestnik of Samara University. History, pedagogics, philology, 2021, vol. 27, no. 1, pp. 129-135

the high level of the performance: a breathtaking last second try, a brilliant second half, to show tremendous character and, as such adjectives as brilliant, tremendous explicitly evaluate the excellent team's performance, the focus of "Victory" frame shifts towards the figure of the winners, by no means concerning their match partners.

\section{Conclusion}

In conclusion, we should say that frames "Victory" and "Defeat" are essential in the introductions of match reports. The frame focus can be shifted due to such cognitive model constituents or peripheral frames as PARTICIPANTS, EVENT, RESULT, MANNER of performance. The author, according to their pragmatic goals, manages to "switch" the focus of the frame to the characteristics of the game, to the reasons of failure or to the peculiarities of teams and their performance by using various evaluative adjectives and words / word combinations bearing both implicit and explicit assessment.

\section{Materials of the research}

Castleford Tigers 2020 - Castleford Tigers: official website 2020. URL: https://www.castlefordtigers.com.

Catalans Dragons 2020 - Catalans Dragons: official website 2020. URL: http://www.catalansdragons.com.

Huddersfield Giants 2020 - Huddersfield Giants: official website 2020. URL: https://giantsrl.com.

Hull FC 2020 - Hull FC official website 2020. URL: https:// www.hullfc.com/.

London Irish 2020 - London Irish: official website 2020. URL: https://www.london-irish.com.

Saint Helens 2020 - St. Helens: official website 2020. URL: https://www.saintsrlfc.com.

Warrington Wolves 2020 - Warrington Wolves: official website 2020. URL: https://warringtonwolves.com.

Wigan Warriors 2020 - Wigan Warriors: official website 2020. URL: https://wiganwarriors.com.

Worcester Warriors 2020 - Worcester Warriors: official website 2020. URL: https://warriors.co.uk.

Kibrik 2003 - Kibrik A.A. (2003) Discourse analysis in a cognitive perspective: Doctor of Philological Sciences thesis. Moscow: Institut iazykoznaniia RAN, 90 p. (In Russ.)

Novikova 2019 - Novikova E.A. (2019) Linguo-cognitive analysis of genres of sports discourse (based on the English language): author's abstract of Candidate's of Philological Sciences thesis. Rostov-on-Don, 22 p. (In Russ.)

Filimonova 2019 - Filimonova E.P. (2019) Implementation of sports discourse in Internet communication: cognitive and pragmatic aspect: author's abstract of Candidate's of Philological Sciences thesis. Maikop, 20 p. (In Russ.)

\section{References}

Caldwell 2020 - Caldwell D. (2020) Sounds of the game: An interpersonal discourse analysis of 'on field' language in sports media. Discourse, Context \& Media, vol. 33, p. 100363. DOI: http://doi.org/10.1016/j.dcm.2019.100363.
Caldwell, Walsh, Vine, Jureidini 2017 - Caldwell D., WalshJ., VineE.W., JureidiniJ. (2017)The Discourse ofSport. Analyses from Social Linguistics. New York: Routledge, 256 p. DOI: http://doi.org/10.4324/9781315644974.

Gamson, Ryan 2005 - Gamson W.A., Ryan Ch. (2005) Thinking about Elephants. Toward a Dialogue with George Lakoff. The Public Eye Magazine, vol. 19, no. 2. Available at:http://www.publiceye.org/magazine/v19n2/gamson elephants.html.

Gee, Handford 2012 - Gee J.P., Handford M. (2012) The Routledge handbook of discourse analysis. New York: Routledge, 712 p. Available at: https://www.pdfdrive.net/ the-routledge-handbook-of-discourse-analysis-d34332132. html.

Hepp, Hjarvard, Lundby 2015 - Hepp A., Hjarvard S., Lundby K. (2015) Mediatization: theorizing the interplay between media, culture and society. Media, Culture \& Society, vol. 37, no. 2, pp. 314-324. DOI: http://doi. org/10.1177/0163443715573835.

Krippendorf 2013 - Krippendorf K. (2013) Content analysis: An introduction to its methodology (3rd ed.). Thousand Oaks, CA: Sage Publications, 456 p. DOI: http:// doi.org/10.2307/2288384.

Liu, Chang 2005 - Liu M.-Ch., Chang Ch.E. (2005) From Frame to Subframe: Collocational Asymmetry in Mandarin Verbs of Conversation. Computational Linguistics and Chinese Language Processing, vol. 10, no. 4, pp. 431-444. Available at:https://www.researchgate. net/publication/253715137_From_Frame to Subframe Collocational_Asymmetry_in_Mandarin_Verbs_of Conversation.

Smith, Stewart 2015 - Smith A.C.T., Stewart B. (2015) Introduction to sport marketing (2nd ed.). London, UK: Routledge. 336 p. DOI: http://doi.org/10.4324/ 9781315776767.

Vicari 2010 - Vicari S. (2010) Measuring collective action frames: A linguistic approach to frame analysis. Poetics, vol. 38, no. 5, pp. 504-525. DOI: http://doi.org/10.1016/j. poetic.2010.07.002.

Boldyrev 1999 - Boldyrev N.N. (1999). Conceptual structures and linguistic meanings. In:Philology and culture: materials of international conference May 12-14, 1999. Tambov, pp. 62-69. Available at: https://elibrary.ru/ item.asp?id=23554357. (In Russ.)

Ivanova 2016 - Ivanova I.V. (2016) Cognitive aspects of implicit evaluation in brief news items in English and American mass-media. Vestnik of Moscow State Linguistic University. Humanities, no. 5 (744), pp. 124-138. Available at: https://www.elibrary.ru/item.asp?id=29848042. (In Russ.)

Kislitsyna, Novikova 2017 - Kislitsyna N.N., Novikova E.A. (2017) Sports discourse in the system of institutional types of discourse. Current Issues in Philology and Pedagogical Linguistics, no. 2 (26), pp. 28-35. Available at: https://www.elibrary.ru/item.asp?id=29744898. (In Russ.)

\section{Библиографический список}

Caldwell 2020 - Caldwell D. Sounds of the game: An interpersonal discourse analysis of 'on field' language in sports media // Discourse, Context \& Media. 2020. Vol. 33. 10 p. DOI: https//doi.org/10.1016/j.dcm.2019.100363. 
Pisareva A.G.

Caldwell, Walsh, Vine, Jureidini 2017 - The Discourse of Sport. Analyses from Social Linguistics. Edited by David Caldwell, John Walsh, Elaine W. Vine, Jon Jureidini. New York: Routledge. 2017. 256 p. DOI: http:// doi.org/10.4324/9781315644974.

Gamson, Ryan 2005 - Gamson W.A., Ryan Ch. Thinking about Elephants. Toward a Dialogue with George Lakoff // The Public Eye Magazine. 2005. Vol. 19, No. 2. URL: http://www.publiceye.org/magazine/v19n2/gamson_ elephants.html.

Gee, Handford 2012 - Gee J.P., Handford M. The Routledge handbook of discourse analysis. New York: Routledge. 2012. 712 p. URL: https://www.pdfdrive.net/the-routledgehandbook-of-discourse-analysis-d34332132.html.

Hepp, Hjarvard, Lundby 2015 - Hepp A., Hjarvard S., Lundby $K$. Mediatization: theorizing the interplay between media, culture and society // Media, Culture \& Society. 2015. Vol. 37, no. 2. P. 314-324. DOI: http://doi. org/10.1177/0163443715573835.

Krippendorf 2013 - Krippendorf K. Content analysis: An introduction to its methodology (3rd ed.). Thousand Oaks, CA: Sage Publications. 2013. 456 p. DOI: http://doi. org/10.2307/2288384.

Liu, Chang 2005 - Liu M.-Ch., Chang Ch.E. From Frame to Subframe: Collocational Asymmetry in Mandarin Verbs of Conversation // Computational Linguistics and Chinese Language Processing. 2005. Vol. 10, no. 4, pp. 431-444. URL: https://www.researchgate.net/ publication/253715137_From_Frame_to_Subframe Collocational_Asymmetry_in_Mandāin_-Verbs_of_Conversation.

Smith, Stewart 2015 - Smith A.C.T., Stewart B. Introduction to sport marketing (2nd ed.). London, UK: Routledge. 336 p. DOI: http://doi.org/10.4324/9781315776767.

Vicari 2010 - Vicari S. Measuring collective action frames: A linguistic approach to frame analysis // Poetics. 2010. Vol. 38, no. 5. P. 504-525. DOI: http://doi.org/10.1016/j. poetic.2010.07.002.

Болдырев 1999 - Болдырев Н.Н. Концептуальные структуры и языковые значения // Филология и культура: материалы международной конференции 12 - 14 мая 1999 г. Тамбов, 1999. C. 62-69. URL: https:// elibrary.ru/item.asp?id=23554357.

Иванова 2016-Иванова И.В. Механизмы формирования имплицитной оценочности в текстах кратких газетных сообщений в английской и американской прессе // Вестник Московского государственного лингвистического университета. Гуманитарные науки. 2016. № 5 (744). C. 124-138. URL: https://www.elibrary. $\mathrm{ru} / \mathrm{item}$.asp?id=29848042.

Кислицына, Новикова 2017 - Кислищьына Н.Н., Новикова E.A. Спортивный дискурс в системе институциональных видов дискурса // Актуальные проблемы филологии и педагогической лингвистики, 2017. № 2 (26), C. 28-35. URL: https://www.elibrary.ru/ item.asp?id=29744898. 